\title{
Measures improving the quality of land former mine as media growing seed trees for the purpose of reclamation
}

\author{
Nurul Anuqrah Waty1, Baharuddin Nurkin², Didi Rukmana ${ }^{3}$ \\ ${ }^{1}$ Environmental Management Study Program of Graduate School, Hasanuddin University. \\ ${ }^{2}$ Department of Tree Physiology and Silviculture, Faculty of Forestry, Hasanuddin University. \\ ${ }^{3}$ Department of Agribusiness, Faculty of Agriculture, Hasanuddin University.
}

Correspondence Author: Nurul Anuqrah Waty. Environmental Management Study Program of Graduate School, Hasanuddin University. Indonesia. Email: nurul.anuqrah95@gmail.com

Received date: 25 January 2020, Accepted date: 25 March 2020, Online date: 14 April 2020

Copyright: (C) 2020 Nurul Anuqrah Waty et al. This is an open-access article distributed under the terms of the Creative Commons Attribution License, which permits unrestricted use, distribution, and reproduction in any medium, provided the original author and source are credited.

\begin{abstract}
This study aims to analyze the nutrient content of ex-mining land and choose the best type of plants for nursery activities as well as plant growth response to compost and NPK fertilizer. This research provides information about the nutrient content available in the former nickel mining land and to find out the types of plants that are good for planting in the old mining area as well as the interaction of plants with planting media. This research is located in the Former Mining Area of PT Kreative Jaya, North Kolaka Regency, South Sulawesi. This type of analysis uses quantitative descriptive methods in the form of field data collection, namely height, diameter, and several plant leaves; field data processing; and laboratory analysis to determine the root shoot ratio. The research method used is orthogonal contrast analysis with two factors and three repetitions. The first factor is the composition of the planting media (ex-mining land (T0), ex-mining land + 1.25 kg compost (T1) and $1.5 \mathrm{~kg}$ (T2); ex-mining ground + $7 \mathrm{~g}$ NPK fertilizer (T3) and NPK $12 \mathrm{~g}$ (T4)). The second factor is the type of Acacia auriculiformis (V1), sengon Paraserianthes falcataria (V2), and kuku Pericopsis mooniana (V3). Data were analyzed using analysis of variance and continued with orthogonal contrast test. The results of the analysis of variance showed that the planting media ( $T$ ) had a significant effect on plant height and number of plant leaves, but had no significant impact on plant stem diameter. Meanwhile, the type of seed (V) significantly affected the increase in plant height, stem diameter, and several plant leaves.
\end{abstract}

Keywords: Acacia auriculiformis, Paraserianthes falcataria, Pericopsis mooniana, NPK, compost, reclamation.

\section{INTRODUCTION}

Development activities, besides having a positive impact, also hurt the preservation of natural resources and the environment. One of the events in utilizing natural resources is the mining of minerals, which until now, is one of the sectors that contribute a large amount of foreign exchange. Energy and mineral mining has experienced rapid progress over the past 20 years. It provides added value if the resources stored in the bowels of the earth are exploited effectively to offer economic benefits to the welfare of the people, regional development, industrial and trade growth, and an increase in national and local income (Samad, 2016) [16].

The existence of mining activities such as nickel mining will undoubtedly be very beneficial for the people in the area around the mine. But according to the results of an interview conducted by Risal et al., in (20150 [14], the presence of coal mines in Makroman did have a positive impact but only a small portion, instead of mining companies shut down most of the livelihoods of people in the Makroman area. In South Sulawesi, North Kolaka Regency is one area that has many mining companies. One of them is PT Kreative Jaya.

The negative impact of mining activities on the environment needs to be controlled to prevent damage beyond normal limits. With the problems caused, a plan is required in order to restore environmental functions so that they can be productive again, such as reclamation and my restoration. One type that is often used for mining reclamation activities is Sengon (Paraserianthes falcataria), Acacia (Acacia auriculiformis) and this study was also carried out by adding one of the pioneer types in the area, namely the nailed wood type (Pericopsis mooniana). Next, we will see whether this land is suitable for planting trees or by applying unique treatments such as adding compost and adding compound fertilizer (NPK) (Ikbal, 2016) [7]. Given compost can increase organic C, N-total soil, base saturation, $\mathrm{P}$, and soil base cation. In addition to adding compost, compound fertilizer 
(NPK) will also be used, which is one of the inorganic fertilizers that can be used efficiently to increase the availability of macronutrients (NPK), replacing single fertilizers such as urea, SP-36, and KCL which are sometimes tricky obtained and expensive (Kaya, 2015) [9].

\section{MATERIALS AND METHODS}

\section{Location, Time and Research Design}

This study was conducted at the site of the former PT Kreative Jaya mine area, Larui village, Kec. Porehu, Kab. North Kolaka. Analysis of soil samples at the Soil Science Laboratory at the Faculty of Agriculture, Hasanuddin University. Analysis of plant samples was carried out at the Silvicultural Laboratory of the Faculty of Forestry, Hasanuddin University. The study was conducted for 12 weeks, from August to November 2019. The research method used was orthogonal contrast analysis with two factors and three repetitions.

\section{Tools and Materials}

The tools used in this study are polybags, ruler, shovel, ground sifter, aliper, analytical scales, markers, labels, plastic samples, cameras, and writing instruments. As well as the materials used in this study are 45 plant seeds aged two months, the former mining soil planting media, compost, NPK fertilizer.

\section{Methods and Data Collection}

The research method used is orthogonal contrast analysis which consists of 2 factors:

The factor I Planting Media Composition (T) consisting of 5 levels where for ex-mining land, each will be used weighing $10 \mathrm{~kg}$.

T0 : ex mine land (control)

$\mathrm{T} 1$ : ex mine land + compost fertilizer $(1.25 \mathrm{~kg} /$ polybag $)$

$\mathrm{T} 2$ : ex mine land + compost fertilizer $(1.5 \mathrm{~kg} /$ polybag $)$

$\mathrm{T} 3$ : ex mine land + NPK compound fertilizer ( $7 \mathrm{~g} /$ polybag $)$

T4 : ex-mining land + NPK compound fertilizer (12 g / polybag)

Factor II Plant Type (V) consisting of 3 levels.

V1: acacia seedlings (Acacia auriculiformis)

V2: sengon seeds (Paraserianthes falcataria)

V3: nail seeds (Pericopsis mooniana)

Based on the two treatment factors, a combination of treatments is obtained by $5 \times 3=15$ treatment units,

Namely, data collection techniques, namely observe variables, which include:

a) Plant height $(\mathrm{cm})$ measured from the base of the stem marked to the top shoot. The height increase data that is processed is the difference between the initial measurement and the final measurement. Observation of plant height is done once a week using a ruler (ruler).

b) The stem diameter $(\mathrm{mm})$ measured at a distance of $2 \mathrm{~cm}$ from the marked surface of the soil. The added diameter data processed is the difference between the initial measurement and the final measurement. Measurements were made using a aliper.

c) The number of leaves (strands) is done by counting the number of sheets that appear during the study. Data added to the number of leaves processed is the difference between initial measurements and final measurements. The number of blades is counted once a week by counting the total number of leaves that have opened correctly.

Laboratory Analysis of

a) Root Shoot Ratio that is the ratio between the dry weight of the top of the plant and the root dry weight at the end of the study and to see the comparison between evaporation and absorption that occurs in plants, using the formula:

$N P A=\frac{B K P(g)}{B K A(g)}$

Note:

NPA = ratio shoots Roots (Top Root Ratio)

BKP = Dry weight Pucuk (Top dry weight)

BKA = Dry weight Root (Root dry weight)

\section{RESULTS}

\section{The content of nutrients available on mined land nickel PT Kreative Jaya}

The availability of nutrients is needed in planting activities for the process of plant development and growth. In addition to nutrients, chemical content in ex-mining land is also necessary to determine the treatment that will be given next. The table below shows the nutrient content available on the former PT Kreative Jaya nickel mine.

Table 1: Results of soil chemical analysis on ex-mining areas

\begin{tabular}{|c|c|c|c|c|c|c|c|c|c|}
\hline No & $\mathbf{p H}$ & $\mathbf{C}$ & $\mathbf{B O}$ & $\mathbf{C} / \mathbf{N}$ & $\mathbf{P}_{\mathbf{2}} \mathbf{O}_{\mathbf{5}}$ & $\mathbf{C a}$ & $\mathbf{M g}$ & $\mathbf{K}$ & $\mathbf{K T K}$ \\
\hline 1 & 5.97 & 1.68 & 2.89 & 11 & 8.63 & 4.12 & 0.85 & 0.68 & 18.63 \\
\hline
\end{tabular}


Citation: Nurul Anuqrah Waty et al., 2020 Measures improving the quality of land former mine as media growing seed trees for the purpose of reclamation. Advances in Environmental Biology, 14(4): 7-13. DOI:10.22587/aeb.2020.14.4.2

\begin{tabular}{|c|c|c|c|c|c|c|c|c|c|}
\hline & (slightly acidic) & (low) & & (moderate) & (very low) & (low) & (low) & (high) & (moderate) \\
\hline \multirow{2}{*}{2} & 6.13 & 1.74 & \multirow{2}{*}{2} & 12 & 8.47 & 6.85 & 0.97 & 0.24 & 19.63 \\
\hline & (slightly sour) & (low) & & (moderate) & (very low) & (moderate) & (low) & (low) & (moderate) \\
\hline \multirow{2}{*}{3} & 6.42 & 2.15 & \multirow{2}{*}{3.7} & 10 & 10.21 & 8.47 & 0.94 & 0.85 & 20.74 \\
\hline & (slightly sour) & (moderate) & & (low) & (low) & (moderate) & (low) & (high) & (moderate) \\
\hline \multirow{2}{*}{4} & 6.19 & 1.89 & \multirow{2}{*}{3.25} & 14 & 6.99 & 3.22 & 1.02 & 0.47 & 18.24 \\
\hline & (slightly sour) & (low) & & (moderate) & (very low) & (low) & $($ low $))$ & (moderate) & (moderate) \\
\hline \multirow{2}{*}{5} & 5.24 & 1.85 & \multirow{2}{*}{2.56} & 12 & 8.56 & 6.56 & 0.82 & 0.54 & 18.96 \\
\hline & (acid) & (low) & & (moderate) & (very low) & (moderate) & (low) & (moderate) & (moderate) \\
\hline
\end{tabular}

Under neutral $\mathrm{pH}$ conditions (6-7), nutrients are easily absorbed by plants because at neutral $\mathrm{pH}$, and some nutrients will dissolve easily in water (Anni, 2017) [2]. In contrast to the soil pH found at the site of the former nickel mine of PT Kreative Jaya, which is classified as somewhat acid, which makes it difficult for nutrients to be absorbed by plants. The C content in the soil is still relatively low, which indicates the lack of soil fertility. Based on research conducted by Afandi et al. in 2015 [1], it was suggested that the provision of organic materials such as compost, cow dung, and chicken manure could increase soil $\mathrm{C}$ organic content.

One of the critical indicators for evaluating the quality of mined soils is soil organic matter content (Rachman et al., 2017) [13]. Based on the table above, it can be seen that the range of organic material available on ex-mining land is between 2-3.5. In a study conducted by Hidayanto et al. in 2015 [5], the results of the C / N ratio were classified as high due to environmental factors such as the high temperature at the composting location and the lack of moisture in the compost, thus inhibiting the decomposition process. Unlike the case with the $\mathrm{C} / \mathrm{N}$ ratio in table 1, which is classified as moderate. In addition to $\mathrm{C} / \mathrm{N}$, which need to be considered next is the Pcontent2O5. Benefits of P2O5 for soil, namely assisting in the process of transporting energy resulting from metabolism in plants, stimulating fruiting and flowering, root growth, seed formation and division of plant cells, and enlarging tissue in plant cells (Roidah, 2013) [15]. For the content of P2O5 in the land of the former nickel mine in PT, Kreative Jaya is classified as very low, so that activities are needed to increase P2O5 so that plants can grow well.

The content of $\mathrm{K}, \mathrm{Ca}$, and $\mathrm{Mg}$ is a macronutrient that is very important for plants. These three nutrients interact with one another in the soil so that a balance of these three nutrients is needed. If there are nutrients that are too high, then the nutrients will be depressed. Research conducted by Wasis and Siti in 2019 [20] shows that very high Ca content will be toxic to sengon plants. Table 1 shows the low $\mathrm{Ca}$ and $\mathrm{Mg}$ content, while for $\mathrm{K}$ element is high, so there is a possibility of nutrient imbalance found in the land of the former mining area.

Sources of organic matter such as straw, husks, leaves, and banana skin waste can be added to the soil to increase organic matter in the ground. Banana leaves and skin contain less lignin and cellulose than straw and husks because the leaves and banana peels undergo faster decomposition. The organic matter with low lignin and cellulose content can accelerate the decomposition process so that it will affect the KTK value and nutrient uptake in the soil (Sapriningsih and Sri, 2015) [15]. This is very good for planting activities, inversely proportional to the amount of the KTK, which is on the land of a former nickel mine that is classified as moderate so that operations are needed to improve it.

\section{Growth and Response of plant growth}

Results of measurements of height, diameter, and the number of plants leave every week have increased from the first week to 12 th week. The growth response of each type of plant can be seen in the diagram below.

\section{a. Plant height}

The results of the analysis of the average increase in seedling height for 12 weeks have varied values. Seedling height increase from each treatment can be seen in Figure 1 below. 


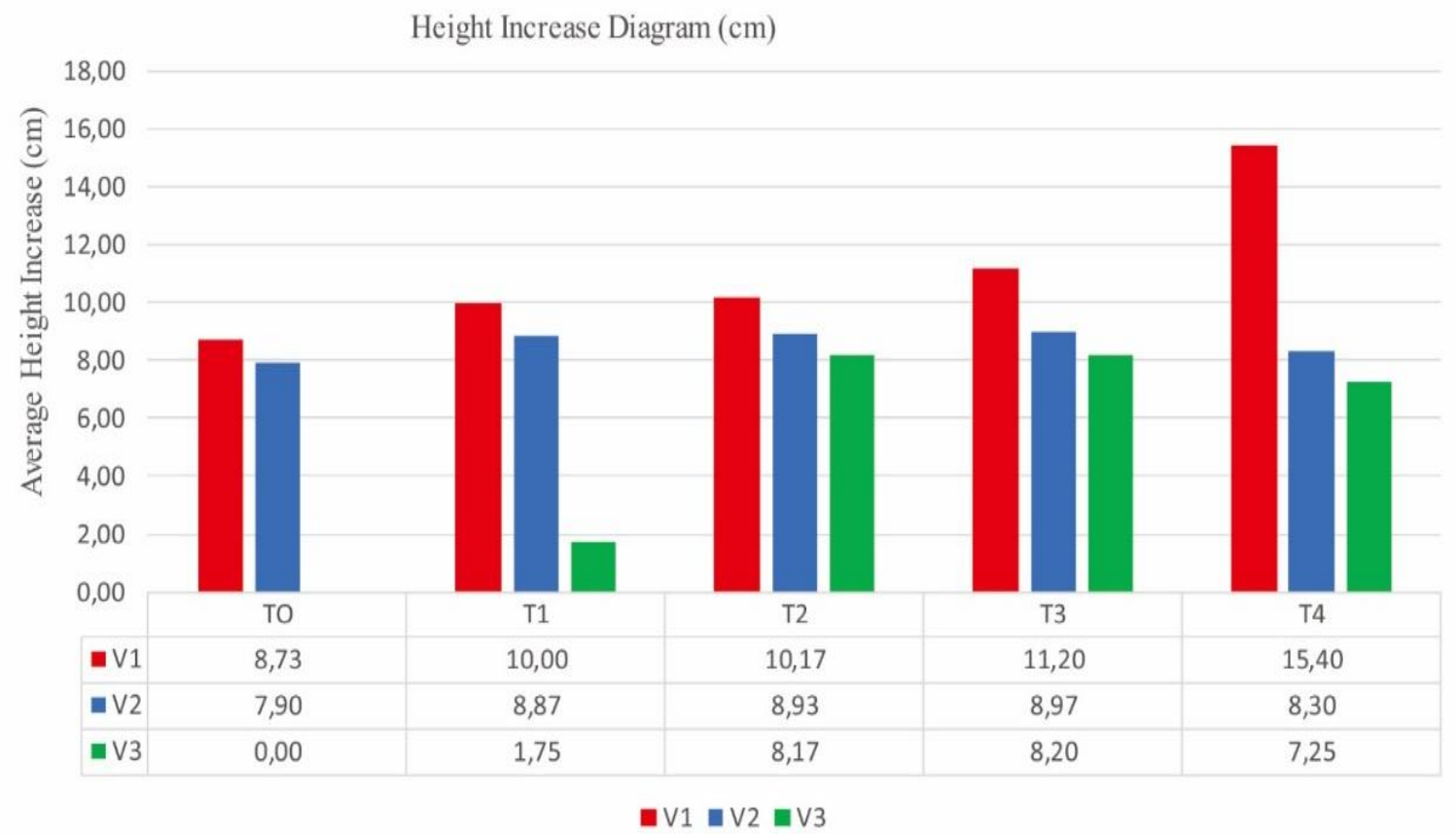

Fig. 1: Graph of the average growth rate of seedling height fo 12 weeks

Figure 1 shows that the treatment of T4V1 shows the highest value of seedling height increase, i.e. the procedure of adding $12 \mathrm{~g}$ NPK fertilizer + acacia seeds with a growth of about $15.40 \mathrm{~cm}$ for 12 weeks observation. Acacia, in general, has been widely planted in ex-mining areas because of its good growing ability and adaptability to acid soils. This species is also commonly planted in the former coal mining area of PT Multi Sarana Avindo (PT MSA) in East Kalimantan and has a role in increasing the revegetation of planted forest biomass in the area (Ilyas, 2010) [8]. Whereas the lowest average height is in the Ttreatment0V3 (ex-mining / control land + nail wood seedlings) where the increase reaches zero because the nail wood seedlings in the treatment can only grow until the 8th week. Suhartati and Didin (2018) [18] conducted a study on nail wood, which was also carried out in a former clay-mining area requiring the addition of compost, sand, and NPK so that plants could grow well. The results of the analysis of variance showed that planting media and seedling species significantly affected the increase in seedling height.

\section{b. Plant diameter}

The results of a summary of the average increase in the diameter of seedlings for 12 weeks have varied values. The increase in plant diameter of each treatment can be seen in Figure 2 below.

\section{Diameter Height Increase ( $\mathrm{mm})$}

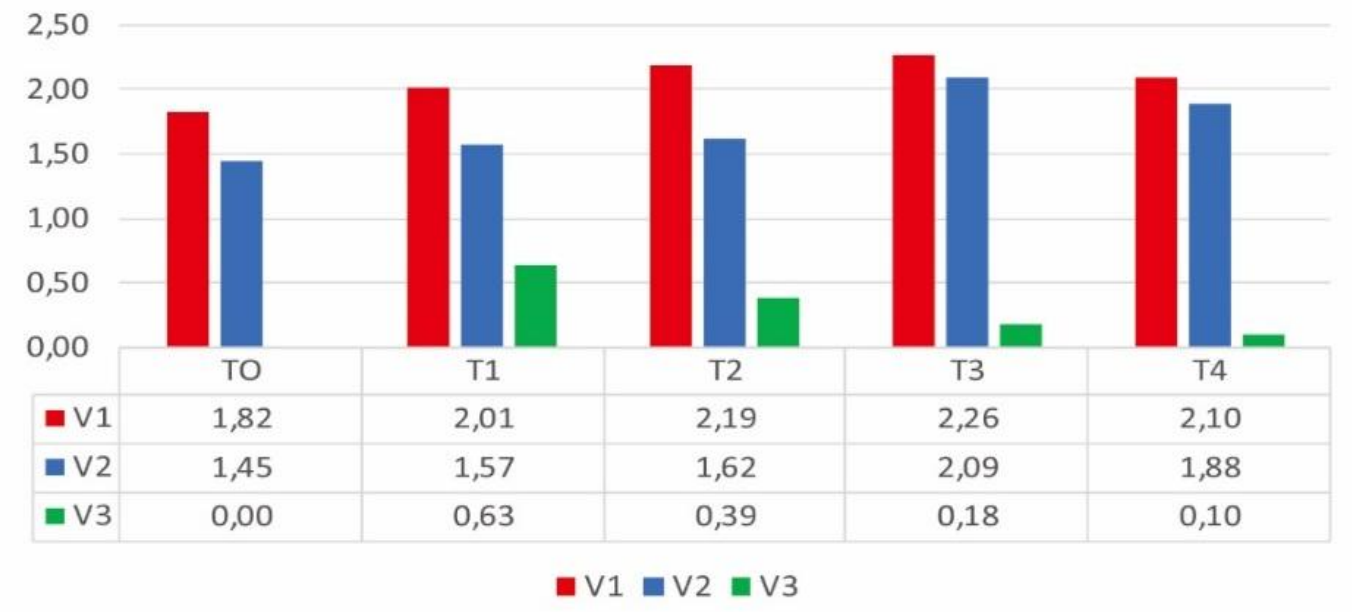

Fig. 2: Graph of the average growth rate of seedling diameter fo 12 weeks

Figure 2 shows above, it can be seen that the highest diameter increase occurred in Ttreatment T3V1 $(2.26 \mathrm{~mm})$, i.e. in exmining soils added with $7 \mathrm{~g}$ NPK fertilizer with acacia plants. Acacia auriculiformis is one of the woody plants that has been widely planted in various places because it belongs to the fast-growing (fast-growing species). Acacia is suitable to be planted in deforested forests for restoration activities or planted in industrial plantations because, in a short time, it can produce large 
biomass $(\mathrm{Hi}, 2009)$ [4] whereas the lowest diameter increase was seen in treatment T0V1 (ex-mining / control soil + nail wood seedlings). Based on the results of experimental design that has made the $\mathrm{T}$ factor (growing media) effect is not real while the factor V (types of seeds) was highly significant.

\section{c. Number of leaves of plants}

Several sheets are one of the variables that can be used to measure the growth of plants other than plant height. Variable observation of the number of layers is needed as an indicator of growth and as a support to explain the growth process that occurs, such as the formation of plant biomass (Ikbal, 2016) [7]. The results of observations for 12 weeks regarding the increase in the number of leaves can be seen in Figure 3 below.

Number of leaf increments (sheet)

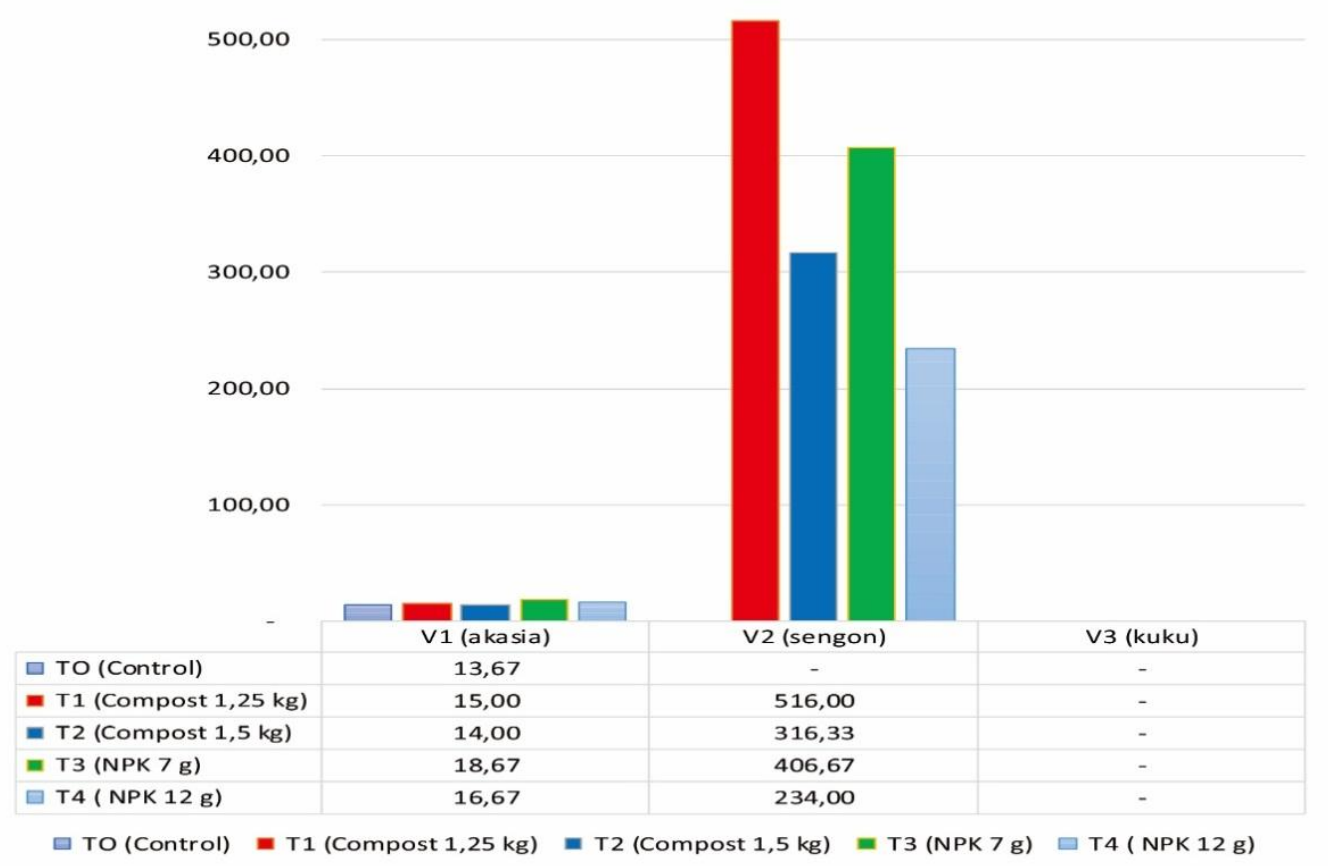

Fig. 3: Graph of the average rate of increase in the number of seedling fo 12 weeks

Figure 3 shows above, the type of sengon experienced the highest average number of leaf increments, namely the Ttreatment $1 \mathrm{~V} 2$ (1.25 kg compost + sengon seedlings). Khalif et al. (2014) [10] in his research concluded that sengon could improve the quality of soil fertility as indicated by an increase in organic matter, $\mathrm{N}$-total, and $\mathrm{N}$-available in soils compared to ex-mining land that is not planted with sengon. The lowest average number of leaves increased in Ttreatment0V3 (ex-mining / control soil + nail wood species). Types of nail wood in this study, the average number of leaves tend to decrease. Whether it's by adding compost or by adding NPK fertilizer, Perala and Wulandari (2019) [11] also examined the effectiveness of nail wood growth. They found that the application of vermicompost, rhizobium, and AMF could not increase the height, diameter, and the number of root nodules but could increase the number of leaves, the amount of chlorophyll, and root length. The results of the environmental analysis showed that the planting media (T) and type of seedlings (V) significantly affected the number of plant leaves.

\section{DISCUSSION}

\section{Increase in plant height}

Sengon (Paraserianthes falcataria) has the right growth height compared to types of wood nails. The best height increase was seen in the T3V2 treatment (NPK fertilizer $7 \mathrm{~g}+$ sengon seedlings), and the lowest height increase was seen in the T0V2 treatment (ex-mining soil + sengon seedlings). Wasis and Siti (2019) [20] researched sengon planted in a former limestone quarry area. They had a significant effect on the growth of height, diameter, number of leaves of sengon seedlings with the application of $5 \mathrm{~g}$ of NPK fertilizer. Sengon plants can also increase soil fertility from the deciduous leaves that produce organic material, increasing the $\mathrm{N}$ content of the soil (Khalif, 2014) [10]. Furthermore, research conducted by Ikbal (2016) [7], where $\mathrm{H} 2 \mathrm{P} 2$ treatment $(1 \mathrm{ml}$ of concentrated humic material/planting hole $+2.5 \mathrm{~kg}$ compost/planting hole) showed the best growth. It is suspected that the higher age of plant growth is more dominant and also due to the influence of tree physiological factors and plant response so that the nutrients available in the soil are still widely used for plant height growth. Not only that, but planting media also has an essential influence on the increase in plant height.

Planting media have a significant effect on increasing the growth of seedling height because the planting media used to have poor organic matter content. Therefore, it is necessary to add compost and NPK fertilizer to provide nutrients needed by plants to develop (Wasis and Sandari, 2011) [19], then added that topsoil as a primary building material for planting media contains various nutrients and minerals that can supply nutrients for growing plant. 


\section{Increase in plant Diameter}

Soil and climate conditions are one of the factors that affect the root system and plant canopy surface, in contrast to diameter growth, which is dependent on relative humidity. Air temperature also influences plant growth, such as increasing the rate of transpiration, which can be characterized by a decrease in relative humidity. If something like this lasts for a long time, it can cause disturbance of plant water balance and can reduce plant growth, including plant diameter (Bustomi and Mira, 2013) [3].

\section{Increase in the number of plant leaves}

The number of leaves is one of the variables that can be used to measure plant growth in addition to plant height. Variable observation of the number of sheets is needed as an indicator of growth and as a support to explain the growth process that occurs, such as the formation of plant biomass. The leaves have stomata, which are the entry point for air and elements that come from the air. A large number of sheets can absorb light, $\mathrm{CO} 2$ and water in large amounts, so photosynthesis increases and organic compounds such as carbohydrates will be formed. The results of photosynthesis will then be distributed to other parts of the plant so that plants can grow and develop (Ikbal, 2016) [7]. Also, this type of acacia has been tested in the area of the former limestone quarry. It can still grow well (without treatment) even though treatment (AMF application) results in better growth (Prayudyaningsih, 2014) [12].

The number of leaves is one of the variables that can be used to measure plant growth in addition to plant height. Variable observation of the number of sheets is needed as an indicator of growth and as a support to explain the growth process that occurs, such as the formation of plant biomass. The leaves have stomata for photosynthesis and produce organic compounds such as carbohydrates. The photosynthesis results will then be distributed to other parts of the plant so that plants can grow and develop. The study was conducted not only to look at the average height of seedlings and average stem diameter but also to see the average growth of leaves in each type of plant.

The average addition of the lowest number of leaves in this study is that without treatment (control). This is consistent with that contained in the Eco Green Journal. The increase in the number of nail wood leaves based on the research of Husna et al. (2017) [6] is by the treatment of FMA Glomus sp. without administration Hyponex red gives the best results. Red FMA and Hyponex types can increase nodulation, root dry weight, shoot a dry load, nodule dry weight, and root number.

\section{CONCLUSIONS}

The nutrient content available in the former PT Kreative Jaya nickel soils is relatively acidic pH, low $\mathrm{C}$ content, average $\mathrm{C} / \mathrm{N}$ ratio, $\mathrm{P} 2 \mathrm{O} 5$ is very low, $\mathrm{Ca}$ content, and $\mathrm{Mg}$ is classified as low, $\mathrm{K}$ is classified as fair, and CEC is classified as fair. The best types of plants for nursery activities in the former nickel mining area are acacia and sengon. The response of plant growth to the addition of compost and NPK fertilizer is different for each treatment. Compost and NPK fertilizers significantly affect the increase in plant height and the number of plant leaves. As for the rise in plant diameter, compost and NPK had no significant effect, while differences in seed types have a significant impact.

\section{ACKNOWLEDGEMENT}

Authors thank Asryadi Pratama, Munawwarah Nawir, Ramdha Mawaddha, and Hardiyanti outstanding support in field and laboratory works.

\section{REFERENCES}

[1] Afandi, F. N., S. Bambang,. N.Yulia, 2015. The effect of giving various types of organic material to the chemical properties of the soil on the growth and production of sweet potato plants at Entisol Ngrangkah Pawon, Kediri.Land Journal and Land Resources, 2 (2). ISSN: 237-244-2015. [in Indonesian]

[2] Anni, Yuniarti. 2017. Effect of Organic fertilizer and liquid organic fertilizer on Ph, N-total, C-organic, and Pakcoy results on Inceptisol.Proceedings of the National Seminar on the Faculty of Agriculture UMJ. 213-219. [in Indonesian]

[3] Bustomi, S. and Y. Mira, 2013. Relationship model of height and diameter of Acacia (Acacia Auriculiformis) as a producer of energy wood in Purwokerto Regency, Central Java Province.Journal of Plantation Forest Research, 10 (3): $155-160$.

[4] Hi, P. H, 2009. Genetic improvement of plantation-grown acacia auriculiformis for sawn timber production. Thesis, Acta Universitatis Agriculturae Sueciae. Upsala: 1-53.

[5] Hidayanto, Muhammad., P. P. Nurul, , and K. Z. Roro, 2015. Development of microbial bio activators of various types of moles for oil palm empty fruit bunch composting in improving the characteristics of coal former soils. Journal of Agricultural Sciences, 6(1): 420-563.

[6] Husna., F. R. Abdal., A. Asrianti., and D. T. Faisal, 2017. Sporulation of local arbuscular mycorrhizal fungi from the nail wood rizofer (Pericopsis Mooniana) influenced by the red hyponex Dose.Ecogreen Journal, 3 (2): 79-87. ISSN 24079049.

[7] Ikbal, 2016. Improving the quality of nickel mining soils for revegetation plant growth media through utilization of humans and compost.Thesis: Bogor Bogor Agricultural University. [in Indonesian]

[8] Ilyas, Sadeli, 2010. Potential of biomass stands results of revegetation of coal mine former land (case study of Acacia Plants in PT Multi Sarana Avindo) East Kalimantan.Journal of Tropical Forestry, 3(2). [in Indonesian]

[9] Kaya, E., 2015. Effects of NPK compost and NPK fertilizer on N-available soil, N-absorption, growth and yield of rice (Oryza sativa L). Agrologia, 2(1). [in Indonesian]

[10] Khalif, U., R. U. Sri,., and K. Zaenal. 2014. The Effect of Sengon (Paraserianthes falcataria) planting on C and N soils in Slamparejo Village, Jabung, Malang.Journal of Land and Land Resources, 1 (1): 09-15. 
[11] Perala, S., and A. S. Wulandari, 2019. Wood kuku (Pricopsis mooniana THW) BREEDING response growth for waste tailings added with vermicompost, rhizobium, and arbuscular mycorrhizal fungus.IOP Conference Series: Earth and Environmental Sciences (394). [in Indonesian]

[12] Prayudyaningsih, Retno. 2014. Growth of alstoniascholaris, acacia auriculiformis and muntingiacalabura seedlings that were inoculated with arbuscular mycorrhizal fungi in the former media of the cretaceous mine.Wallacea Forestry Research Journal, 3 (1): 13-23.

[13] Rachman, Achmad., I, Irawan., I. W. Suastika., and Sutono. 2017. Soil quality indicators on former mining land.Journal of Land Resources, 11 (1). ISSN 1907-0799. [in Indonesian]

[14] Risal, S., D. B. Paranoan, , and S. Djaja. 2015. Analysis of the impact of mining policies on the socio-economic life of communities in Makroman Village.Administrative Reform Journal, 1(3). [in Indonesian]

[15] Roidah, I. S, 2013. Benefits of using organic fertilizer for soil fertility. Journal of Tulungagung University. 1(1). ISSN: 2339-0352. [in Indonesian]

[16] Samad, Foniike, 2016. The impact of nickel mining on society's socio-economic-ecology in Wasilla District, east Halmahera Regency. Thesis: IPB. Bogor. [in Indonesian]

[17] Sapriningsih, Endang and Sri, Haryanti. 2015. Cellulose and lignin content of various sources of organic ingredients after decomposition in latosol soil. Bulletin of Anatomy and Physiology. 23(2): 34-42. [in Indonesian]

[18] Suhartati and Didin, A. 2018. Breeding techniques of nail wood species (pericopsis mooniana) for reclamation of clay mine land.FALOAK Journal. 2 (2): 103-114. [in Indonesian]

[19] Wasis, Basuki and H. S. Sandari. 2019. Growth of Sengon Seedlings (Paraserianthes Falcataria) in the Former Media of the Limestone Mine with the Addition of Compost and NPK Fertilizers. Journal of Tropical Silviculture. 9 (1): $51-57$. ISSN: 2086-8227.

[20] Wasis, Basuki and H. S. Siti, 2019. Growth of sengon semai (paraserianthes falcataria) in the former media of the limestone mine with the addition of compost and npk fertilizers.Journal of Tropical Silviculture, 9 (1):51-57. ISSN: $2086-8227$. [in Indonesian] 